\title{
WUJUD ISLAM RAHMATAN LIL ÂLAMIN DALAM KEHIDUPAN BERBANGSA DI INDONESIA
}

\author{
Muhammad Nur Jamaluddin \\ Magister Ilmu Hukum Tata Negara Universitas Padjadjaran \\ E-Mail: muhnurjamaluddin@gmail.com
}

\begin{abstract}
The realization of Islam Rahmatan Lil'alamin both in the world in general and in Indonesia in particular is facing problems such as violence, extremism, radicalism, and terrorism on behalf of Islamic religion. This research is a literature study that discusses the concept of Islam Rahmatan Lil'alamin with a comprehensive and holistic is important in the midst of the strengthening of discourse and action between the Islamic movements in Indonesian nationality. Rahmatan Lil'alamin as an embodiment of Islamic ideals in nationality can be acctualized by 3 (three) ways, namely: (1) have extensive knowledge and understand the development of technology and science; (2) Not the emotion in Bergama; and (3) be careful in every speech, deed, and action.
\end{abstract}

Keywords: Rahmatan Lil'alamin; Islamic Ideals; Nationality

\begin{abstract}
Abstrak
Perwujudan Islam Rahmatan Lil'alamin baik di dunia secara umum maupun di Indonesia pada khususnya sedang menghadapi permasalahan seperti adanya kekerasan, ekstremisme, radikalisme, dan terorisme yang mengatasnamakan agama Islam. Penelitian ini merupakan studi literatur yang membahas konsep Islam Rahmatan Lil'alamin dengan secara komprehensif dan holistik yang menjadi penting di tengah menguatnya kontestasi wacana dan aksi di antara gerakan Islam dalam kebangsaan Indonesia. Rahmatan Lil'alamin sebagai perwujudan cita-cita Islam dalam kebangsaan dapat diaktualisasikan dengan 3 (tiga) cara, yaitu: (1) memiliki ilmu pengetahuan yang luas dan memahami perkembangan teknologi dan sains; (2) tidak emosi dalam bergama; dan (3) hati-hati dalam setiap ucapan, perbuatan serta tindakan.
\end{abstract}

Kata-kata Kunci: Rahmatan Lil'alamin; Cita-Cita Islam; dan Kebangsaan 


\section{Pendahuluan}

Islam adalah agama yang menjunjung tinggi nilai-nilai universal, humanis, dinamis, kontekstual dan abadi sepanjang masa. Selain itu agama Islam merupakan agama yang telah Allah SWT sempurnakan untuk menjadi pedoman hidup manusia yang terdapat dalam Alquran yang diturunkan kepada Nabi Muhammad SAW sebagai rasul terakhir dan penutup para nabi sebelumnya melalui malaikat Jibril sebagaimana tertuang dalam (Qs. Al-Ahzâb/33: 40). ${ }^{1}$

Indonesia dan Islam adalah gambaran gagasan dan kebenaran yang harus dikuatkan pondasinya, mengingat sejarah masuknya Islam ke Indonesia pada 7 Masehi silam. Islam menjadi agama yang diakui dan menjadi agama mayoritas di Indonesia. Penyebaran Islam ke pelosokpelosok nusantara menggunakan beragam metode dan penyebaran menyebabkan banyak perbedaan budaya merupakan perwujudan dalam beberapa amalan, seperti penyebaran dengan wayang oleh beberapa wali di daerah Jawa, atau melalui musik-musik. ${ }^{2}$ Perbedaan penyebaran tersebut, bukan merupakan halangan mewujudkan kesatuan dalam ketaqwaan kepada Allah melalui Islam, karena Rahmatan Lil'alamin bukan merupakan milik suatu golongan melainkan milik seluruh alam.

Menurut KH. Abdul Muchith Muzadi kakak KH. Hasyim Muzadi bahwa Islam Rahmatan Lil'alamin merupakan konsep yang komprehensif dan holistik, didalamnya terdapat nilai persaudaraan, perdamaian dan kebijaksanaan yang mudah diterima oleh masyarakat ketika disebarkan oleh para mubalighin (penyebar dan pembawa agama) melalui ustadz, ulama, dan habib di Indonesia. ${ }^{3}$

Di dalam Alquran, Allah banyak menulis mengenai bangsa-bangsa terdahulu yang telah menemui ajalnya. Bangsa-bangsa tersebut menerima hukuman karena kelalaian masyarakatnya, karena ketidaktaatan kepada pemimpin atau karena berbuat kerusakan, seperti pada Qs. AlIsra/17: 58 yang artinya: "Dan tidak ada suatu negeri pun (yang durhaka penduduknya), melainkan Kami binasakannya sebelum hari kiamat atau

1 Rasyid, Muhammad Makmun. 2016. Islam Rahmatan Lil Alamin Perspektif KH. Hasyim Muzadi. Episteme Jurnal Pengembangan Ilmu Keislaman, Vol. 11, No.1: 94.

2 Cabil. "Perwujudan Cita-cita Islam dalam Kebersamaan Kebangsaan". (http://coretanceritacrayon.blogspot.com/2017/10/perwujudan-cita-cita-islamdalam.html), diakses pada tanggal 25 Desember 2019, pukul 16.34 WIB.

${ }^{3}$ Muzadi, Abdul Muchith. Mengenal Nahdlatul Ulama. (Surabaya: Khalista, 2006), hlm. 1. 
Kami siksa (penduduknya) dengan siksa yang sangat keras". Sebelumnya Allah memperingatkan bahwa setiap umat atau penduduk yang meyakini Islam, memiliki batas waktu dan ajalnya sendiri (Qs. Al-Araf, Qs. Yunus, Qs. Al-Hijr) dan setiap batas waktu tersebut tidak dapat dipercepat maupun diperlambat. Oleh karena itu, manusia memiliki kesempatan untuk menjadi bagian dari akhir umat/bangsa yang baik atau malah sebaliknya.

Konflik kepentingan banyak terjadi dengan mengatasnamakan keadilan dan kesejahteraan. Namun, tidak sedikit yang berakhir merugikan berbagai pihak. Beberapa kerugian yang disebabkan konflik kepentingan bahkan mengatasnamakan Islam hingga akhirnya membunuh sesama manusia. Adapun contohnya yaitu kasus bom Bali I yang terjadi pada tanggal 12 Oktober 2002, kemudian kasus bom Bali II yang terjadi pada tanggal 1 Oktober 2005. ${ }^{4}$ Selain itu ada kasus pascabom bunuh diri di Polrestabes Medan, Sumatera Utara yang terjadi pada Selasa 19 November 2019, dan telah ditangkap oleh Densus 88 Antiteror Polri sebanyak 71 (tujuh puluh satu) orang terduga teroris dalam kasus tersebut. ${ }^{5}$

Keadaan umat Muslim saat ini baik di dunia maupun di Indonesia belum mampu membawa agama Islam secara baik dan benar. Hal tersebut menjadi salah satu bagian yang membuat Islam menjadi kurang dari nilai-nilai kedamaian yang diharapkan sebagaimana mestinya atau bahkan dikenal dengan "ketinggian ajaran Islam tertutup oleh perilaku umat Muslim sendiri (Al-Islâm mahjûbun bil-Muslimîn)", sebagaimana hal ini disampaikan oleh Muhammad Abduh. Selain itu ada pendapat dari Muhammad Iqbal yang menyatakan bahwa keadaan umat Muslim yang dianggap mundur, bukanlah disebabkan ajaran agamanya, tetapi kesalahan terletak pada diri masing-masing pribadinya yang keliru dalam memahami ajaran agama akibat kejumudannya, bahkan sesuatu yang diamalkan bertolak belakang dari sumber aslinya. ${ }^{6}$

Kerancuan memahami Islam dapat dikurangi melalui peningkatan intelektual secara optimal, salah satu upaya konkretnya yaitu melalui

4 Yahya, Ismail. "Islam Rahmatan Lil'alamin". (http://www.iainsurakarta.ac.id/?p=12750), diakses pada tanggal 25 Desember 2019, pukul 16.44 WIB.

5 Liputan6.com, Jakarta. "71 Terduga Teroris Ditangkap Usai Bom Bunuh Diri Medan". (https://www.liputan6.com/news/read/4114911/71-terduga-teroris-ditangkap-usai-bom-bunuh-diri-medan), diakses pada tanggal 25 Desember 2019, pukul 16.50 WIB.

${ }^{6}$ Munawwir, Imam. Salah Paham Terhadap Alquran. (Surabaya: PT Bina Ilmu, 1983), hlm. 115. 
proses pendidikan. Pendidikan dapat ditempuh seseorang secara formal, non-formal dan informal yang bertujuan untuk mendapatkan ilmu pengetahuan dan pemahaman teknologi serta sains yang terus berkembang dalam kehidupan masyarakat, sehigga diharapkan mampu membentuk pribadi Muslim yang berintelektual dan bertaqwa kepada Tuhan Yang Maha Esa. Umat Islam dipersilakan untuk mengembangkan ilmu pengetahuan dan teknologi serta sains sesuai kemampuan akal dan pikirannya sebagaimana tercantum dalam Alquran bahwa manusia memiliki keterbatasan. Namun, keterbatasan itu tidak menjadikan manusia untuk bermalas-malasan karena menurut M. Quraish Shihab, umat Muslim dikenal sebagai yang tidak larut dalam spritualisme tetapi juga tidak hanyut dalam alam materialisme atau ummatan wasathan (umat pertengahan). ${ }^{7}$

Berdasarkan Qs. Al-Rûm/30: 30 bahwa keanekaragaman yang kokoh merupakan bagian dari fitrah manusia. Karen Armstrong menyatakan bahwa agama yang penuh kasih sayang merupakan agama yang sejuk dan menjadi fitrah manusia. ${ }^{8}$ Perdamaian dan kerukunan beragama dapat melahirkan kesejukan dan kedewasaan dalam beragama, hal tersebut merupakan salah satu cita-cita Islam Rahmatan Lil'alamin yang diharapkan menjadi rahmat bagi seluruh alam bukan hanya lintas suku, agama, ras dan antar gologongan, bahkan tidak seperti asumsi iblis ketika Allah akan menciptakan manusia sebagaimana tercantum dalam (Qs. AlBaqarah/2: 30).

Islam Rahmatan Lil'alamin senantiasa selalu menerapkan nilai-nilai perdamaian, persaudaraan, toleransi, kesantunan dan keseimbangan dalam kehidupan di dunia, khususnya di Indonesia. Adapun hubungannya dengan perwujudan cita-cita Islam dalam kebangsaan Indonesia adalah Islam Rahmatan Lil'alamin yang diharapkan dapat menjadi rahmat bagi seluruh alam, termasuk salah satunya kehidupan manusia. Manusia sebagai warga negara yang memiliki kehidupan berbangsa dan bernegara tentu didalamnya mempunyai perbedaan meliputi perbedaan suku, agama, ras, dan antar golongan. Namun, hal ini dapat dipersatukan dengan Bhineka Tunggal Ika (berbeda-beda tetap satu), yang bermakna bahwa persatuan dalam perbedaan, dan perbedaan untuk persatuan di Negara Kesatuan Republik Indonesia.

${ }^{7}$ Shihab, M. Quraish. Wawasan Al-Quran: Tafsir Maudhu'i Atas Pelbagai Persoalan Umat. (Jakarta: Mizan, 1998), hlm. 34.

8 Armstrong, Karen. Compassion: 12 Langkah Menuju Hidup Berbelas Kasih, Terjemahan Yuliani Liputo. (Bandung: Mizan, 2012), hlm. 77. 
Perwujudan Islam Rahmatan Lil'alamin dalam konteks dunia Islam pada umumnya dan Indonesia pada khususnya sedang mengahadapi persoalan yang berkebalikan dengan konsep Islam Rahmatan Lil'alamin yang sebenarnya seperti adanya kekerasan, ekstremisme, radikalisme, dan terorisme yang mengatasnamakan agama Islam. Kehadiran gagasan Islam Rahmatan Lil'alamin ini menjadi penting di tengah menguatnya kontestasi wacana dan aksi di antara gerakan Islam di Indonesia. Berdasarkan uraian tersebut perlu kiranya pembahasan lebih lanjut mengenai Rahmatan Lil'alamin Sebagai Perwujudan Cita-Cita Islam Dalam Kebangsaan.

\section{Metodologi}

Jenis penelitian yang digunakan adalah pendekatan kualitatif, yaitu penelitian yang digunakan untuk meneliti pada kondisi objek alamiah. Peneliti adalah sebagai instrumen kunci, teknik pengumpulan data dilakukan secara kualitatif, analisis data bersifat induktif/kualitatif, dan hasil penelitian kualitatif lebih menekankan makna daripada generalisasi. ${ }^{9}$ Jenis penelitian termasuk dalam penelitian eksploratif yaitu dilakukan untuk mengetahui dan menjelaskan permasalahan yang awalnya peneliti hanya memahami permasalahan yang ada secara umum, baru kemudian peneliti melakukan penelitian. Penelitian eksploratif memiliki masalah yang belum pernah dijejaki, dan berusaha menemukan atau mengungkap permasalahan yang sedang dibutuhkan atau akan diteliti tersebut. ${ }^{10}$ Metode penelitian menggunakan studi literatur yaitu peneliti menelaah secara teliti bahan kepustakaan yang diperlukan dalam penelitian dan juga mengkombinasikan dengan menggunakan wawancara pada informan yang diperlukan dalam penelitian. ${ }^{11}$

\section{Konsep Islam Rahmatan Lil'alamin}

Secara terminologi bahasa Islam Rahmatan Lil'alamin terdiri atas Islam dan Rahmatan Lil'alamin. Islam berasal dari kata salama/salima artinya damai, keamanan, kenyamanan, dan perlindungan. Fatwa tentang Terorisme dan Bom Bunuh Diri yang disampaikan oleh Muhammad

9 Sugiyono. Metode Penelitian Kuantitatif, Kualitatif, dan Kombinasi (Mixed Methods). (Bandung: Alfabeta, 2014), hlm. 9.

${ }^{10}$ Bugin. Metodologi Penelitian Kualitatif. (Jakarta: Rajawali Pers, 2011), hlm. 50.

11 Nazir, Moh. Metode Penelitian. ((Jakarta: Ghalia Indonesia, 2014), hlm. 79. 
Tahir-ul-Qadri menyatakan bahwa: "seperti makna literalnya, Islam adalah pernyataan absolut tentang perdamaian. Agama Islam adalah manifestasi damai itu sendiri. Islam mendorong manusia untuk menciptakan hidup proporsional, damai, penuh kebaikan, keseimbangan, toleransi, sabar, dan menahan marah."12 Kata Islam yang terdevirasi sehingga menjadikan Islam memiliki varian makna yang diafirmasi oleh Alquran sendiri, meliputi: selamat dan sejahtera (Qs. Maryam/19: 47), damai (Qs. Al-Anfâl/8: 61 dan Qs. Al-Hujurât/49: 9), bersih dan suci (Qs. Asy-Syu'arâ'/26: 89, Qs. Al-Maidah/5: 6 dan Qs. As-Shaffât/37: 84), menyerah (Qs. An-Nisâ/4: 125 dan Qs. Ali Imrân/3: 83), penyerahan diri secara totalitas kepadaNya (Qs. Al-Baqarah/2: 208 dan Qs. As-Shaffât/37: 26). ${ }^{13}$

Selanjutnya makna "rahmat" menurut Ibnu Mandzur adalah alriqqatu wa al-ta'attufi (kelembutan yang berpadu dengan rasa keibaan). ${ }^{14}$ Selain itu bermakna kelembutan hati, kehalusan dan belas kasihan sebagaimana pendapat ini disampaikan oleh Ibnu Faris, pun bahwa kata rahima bermakna hubungan kerabat, persaudaraan, dan ikatan darah. ${ }^{15}$ Hal tersebut dipertegas oleh Al-Asfahani bahwa rahmat merupakan alihsân al-mujarrad dûna al-riqqat (kebaikan tanpa belas kasih) dan alriqqat al-mujarradah (belas kasih semata-mata). ${ }^{16}$ Penjelasannya bahwa apabila rahmat disandarkan kepada manusia, maka hanya kebaikan berupa simpati semata dari manusia itu sendiri, sedangkan apabila disandarkan terhadap Allah SWT, maka bermakna kebaikan semata-mata datangnya hanya dari Allah SWT Yang Maha Kuasa.

Adapun makna rahmat dalam Alquran salah satunya terdapat dalam Qs. Al-Anbiyâ'/21: 107 yang artinya "Dan tiadalah Kami mengutus kamu, melainkan untuk (menjadi) rahmat bagi semesta alam. Artinya bahwa rahmat dalam Alqruan hanya dari Allah SWT Sang Pemberi Rahmat bagi semua maklukNya. Rahmat yang diberikan Allah SWT

12 Tahir-ul-Qadri, Muhammad. Fatwa tentang Terorisme dan Bom Bunuh Diri. (Jakarta: LPPI, 2014), hlm. 74.

13 Rasyid, Muhammad Makmun. Op.Cit., hlm. 98-99.

${ }^{14}$ Mandzur, Ibnu. Lisânul Arab. Vol. 5. (Beirut: Dâr Ihyâ Al-Turâts Al-Arabi, 1999), hlm. 173, dalam Muhammad Makmun Rasyid, Op.Cit., hlm. 102.

15 Ahmad, Abi Husain Ibn Faris Ibn Zakariya, Mu'jam Maqâyîsu Al-Lughati, ditahqiq Abd Salam Muhammad Harun. Vol. 2. (Beirut: Dâr Al-Fikr, 1979), hlm. 498, dalam Muhammad Makmun Rasyid, Op.Cit., hlm. 102.

16 Al-Husain, Abi Al-Qasim Ibn Muhammad (Al-Asfahani), Al-Mufradâtu Fî Gharîbi Al-Qur'âni. Vol. 2. (Mekkah: Maktabah Nizâr Mustafa Al-Bâz, 2009), hlm. 253-254, dalam Muhammad Makmun Rasyid, Op.Cit., hlm. 102. 
kepada makhluknya dapat berupa kemenangan, kebaikan, kenikmatan, kasih sayang, dan banyak lagi. Rahmat merupakan sifat rahman Allah SWT yang terkandung di dalam Alquran, dapat diterima dan dirasakan oleh seluruh umat manusia bahkan oleh seluruh alam. Pun Nabi Muhammad SAW dilahirkan ke bumi dijadikan sebagai rahmat dari Allah SWT, sebagaiman sabdanya: "Yâ ayyuha al-nâsu, innamâ anâ rahmatun muhdâtun (wahai sekalian manusia, sesungguhnya aku adalah rahmat yang dihadiahkan Allah)".17

Azab Allah lebih sempit, daripada luasnya rahmat Allah SWT. KH. Hasyim Muzadi menafsirkan bahwa rahmat (rahman) dan rahim Allah itu berbeda. Rahmat (rahman) itu berlaku diterima dan dirasakan oleh semua makhluNya, baik yang Muslim maupun non-Muslim, sedangkan rahim hanya dapat diterima dan dirasakan oleh orang-orang yang bertaqwa kepada Allah SWT, melaksanakan semua perintahnya dan menjauhi semua larangnya sebagai salah satu cara masuk surgaNya, termasuk percaya bahwa tiada Tuhan selain Allah SWT dan Nabi Muhammad SAW adalah rasulNya. ${ }^{18}$

Perbedaan signifikan Islam Rahmatan Lil'alamin yang bersumber dan tercantum dalam Alquran (building in Islam) dengan Islam Liberal dan Islam Pluralis, Islam Progresif, Islam Nusantara, Islam Kalap dan Islam Karib, Islam Berkemajuan, dan sebagainya. Islam Rahmatan Lil'alamin merupakan salah satu solusi untuk dunia karena visi Islam penuh dengan kedamaian, persaudaraan, dan toleransi yang penuh rahmat untuk seluruh alam. Selain itu Islam Rahmatan Lil'alamin yang diajarkan melaui Nabi Muhammad SAW berdampak komprehensif, holistik, inklusif dan positif, tidak memiliki kelemahan dan atau kekurangan, selalu suci dan autentik berdasarkan IlahiahNya. ${ }^{19}$

Ada beberapa upaya dalam menghindari asumsi-asumsi negatif terhadap Islam yang kian telah berkembang, salah satunya mengenai "makhluk yang sama", yaitu "Islam yang tunduk dan tersubordinasikan kepada Barat." 20 Islam Nusantara merupakan salah satu contoh represen-

17 Abdillah, Abi Muhammad bin Abdirrahman bin Al-Fadhl al-Darami. Kitâb AlMusnad al-Jâmi. (Beirut: Dâr Al-Basyâ'ir Al-Islâmiyah, 2014), hlm. 98, dalam Muhammad Makmun Rasyid, Op.Cit., hlm. 103.

18 Rasyid, Muhammad Makmun. Op.Cit., hlm. 98-99.

19 Ibid.

20 Husaini, Adian dan Nuim Hidayat. Islam Liberal: Sejarah, Konsepsi, Penyimpangan dan Jawabannya. (Jakarta: Gema Insani Press, 2002), hlm. 33. 
tati dari Nahdatul Ulama yang belum memiliki definisi resmi, sehingga menjadikan pemahaman Islam yang esklusif. Hal ini cenderung memberikan amgbiguitas dalam praktik, meskipun disebut sebagai bagian budaya khas Indonesia, yang dikhawatirkan menimbulkan saling kecurigaan.

Adapun hadits-hadits Nabi Muhammad SAW yang mengilustrasikan makna Islam Rahmatan Lil'alamin, antara lain:

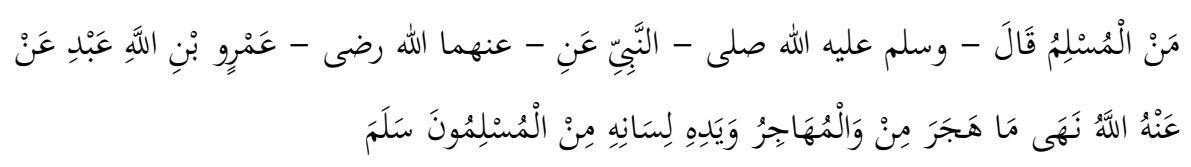

Dari Abdullah bin 'Amru. Nabi Muhammad SAW bersabda, "Seorang muslim adalah orang yang kaum Muslimin selamat dari (kejahatan) lisan dan tangannya, dan seorang Muhajir adalah orang yang meninggalkan apa yang dilarang oleh Allah." (HR. AlBukhari No.10, dan Muslim No.40).

Dalam sebuah hadits disebutkan: "Ada seorang yang bertanya kepada Rasûlullâh Shallallahu 'alaihi wa sallam, 'Wahai Rasûlullâh Shallallahu 'alaihi wa sallam, Islam yang bagaimanakah yang paling baik ?'

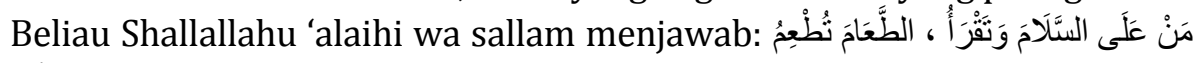

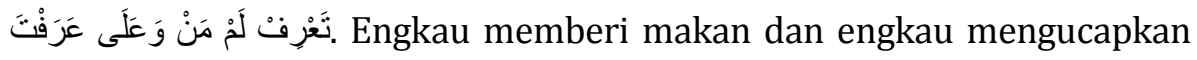
salam kepada orang yang engkau kenal maupun yang tidak kenal." (HR. Al-Bukhâri No.12 dan Muslim No.39, dari Ibnu 'Umar Radhiyallahu anhuma)

Selain itu, dalam hadits riwayat An-Nasa'i, Nabi Muhammad SAW bersabda, وأمو الهم دمائهم على الناس أمنه من و المؤمن. "Seorang muslim itu adalah orang yang orang-orangnya manusia lainnya merasa aman (kejahatan) lisan dan tangannya dan orang mukmin adalah orang yang manusia lainnya merasa aman atas darah (jiwa) dan harta mereka."

Berdasarkan 3 (tiga) hadits di atas menjelaskan bahwa Islam merupakan perwujudan keselamatan dan kedamaian untuk seluruh alam, termasuk umat manusia didalamnya. Kata rahmat yang berarti sebagai kasih saying dan Lil'alamin berarti sebagai seluruh alam dalam istilah Islam Rahmatan Lil'alamin terdapat di dalam (Qs. Al-Anbiyâ'/21: 107). Adapun salah satu tafsir terhadap ayat tersebut disampaikan oleh AthThabari di dalam Jami'ul Bayan Fi Ta'wil Alquran: apakah rahmat itu dengan diutusnya Nabi Muhammad SAW ditujukan kepada seluruh alam, termasuk orang-orang kafir, atau hanya kepada orang-orang yang 
beriman saja? Ada dua pendapat yang disampaikan oleh Ath-Thabari, pertama: bahwa rahmat bagi orang yang beriman berasal dari Allah SWT yang bertujuan untuk memberikan petunjuk dengan cara memasukkan keimanan kepada seseorang agar mampu mengerjakan amal kebaikan yang diperintah Allah SWT dan menjauhi semua laranganNya. Kedua, bahwa makna rahmat bagi orang kafir itu diberikan oleh Allah SWT berupa penundaan bencana (bala), sebagaimana hal tersebut pernah Allah turunkan kepada umat-umat yang dahulu mendustakan para nabi dan rasul Allah. ${ }^{21}$

Beberapa uraian di atas berusaha menunjukan konsep Islam Rahmatan Lil'alamin sebagaimana mestinya, namun masih terlihat begitu abstrak. Ada pengertian yang menjelaskan konsep Islam Rahmatan Lil'alamin melalui operasionalisasi yaitu dari Nur Syam bahwa konsep dan upaya orang Islam di dunia umumnya, khususnya di Indonesia dalam mewujudkan Islam sebagai rahmat bagi seluruh alam itu, berarti bukan hanya keselamatan dan kedamaian untuk semua manusia tetapi juga untuk alam lainnya, meliputi hablum minallah, hablum minan nas dan juga hablum minal alam. Artinya bahwa keselamatan manusia tidak ada artinya jika alam dan sekitarnya tidak dalam keselamatan. Islam yang menyelamatkan adalah Islam yang memberikan keselamatan bagi semuanya sehingga terwujud perdamaian dan kesejukan bagi seluruh alam. ${ }^{22}$

Selain itu Nur Syam menyatakan pula bahwa konsep Islam Rahmatan Lil'alamin berupaya untuk mengembangkan pola hubungan yang terjadi antara manusia baik yang humanis, dialogis, toleran bahkan pluralis, hal tersebut dilakukan dengan pengelolaan, pemenfaatan dan pendayagunaan alam dengan penuh rasa kasih dan sayang. Pluralis dalam arti memiliki relasi tanpa memandang suku, bangsa, agama, ras ataupun titik lainnya yang membedakan antara satu orang dengan orang lain. Humanis dalam arti menjunjung tinggi hak asasi manusia dan menghargai manusia sebagai manusia. Dialogis dalam arti semua persolan yang muncul sebagai akibat interaksi sosial didiskusikan secara baik dan akomodatif terhadap beragam pemikiran. Toleran dalam arti memberi

21 Ath-Thabari. Jami'ul Bayan fi Ta'wil Alquran. (Beirut: Mua'assasah Ar-Risalah, 2000), Al-Maktabah Asy-Syamilah, hlm. 224-310/838-923, dalam Ismail Yahya, Op.Cit.

22 Syam, Nur, Merumuskan Islam Rahmatan Lil'alamin, (http://nursyam.uinsby.ac.id/?p=514), dalam Ismail Yahya, Op.Cit. 
kesempatan kepada yang lain untuk melakukan sebagaimana yang diyakininya, dengan penuh rasa damai. ${ }^{23}$

\section{Konsep Nilai-nilai Keislaman dalam Kebangsaan}

Islam yang diyakini sebagai agama kepercayaan oleh umat Islam, memiliki konsepsi keyakinan, norma-norma, dan tata aturan yang diyakini dilaksana oleh penganutnya secara konsisten dan konsekuen. Islam yang memiliki aturan lengkap dan komprehensif, berfungsi pula sebagai pengontrol dan pengawas, memberikan sanksi dan juga penghargaan menjadikan Islam sebagai agama yang sempurna. Berdasarkan hal tersebut, sudah seharusnya umat Islam mampu mengamalkan ajaran Islam secara tawadhu guna mencapai kualitas hidup yang aman, nyaman, dan sejahtera baik di dunia maupun kelak di akhirat.

Nilai-nilai keislaman yang terdapat dalam kebangsaan dapat dijelaskan dalam dua paradigma, yaitu: ${ }^{24}$ Paradigma pluralisme sebagai upaya persatuan, nasionalisme dan Islam yang mempunyai hubungan positif. Islam sebagai contoh membentuk nasionalisme yang dapat melahirkan bangsa adalah negara Madinah yang didirikan oleh Nabi Muhammad SAW. Paradigma universalisme, maksudnya Islam bertentangan dengan kebangsaan: menurut Mansur. Mansur menyatakan bahwa agama Islam yang universal tidak pernah membatasi peruntukannya bagi siapa dan dimanapun saja. Namun, Islam hadir dalam setiap wilayah kebangsaan. "Cinta tanah air sebagian dari iman" pepetah menyatakan seperti itu, artinya bahwa bagian salah satu dari iman adalah cinta tanah air yang menjunjung tinggi nilai nasionalisme. Mansur menyatakan juga bahwa Islam tidak bertanah air, tetapi penganutnya (umat Islam) pasti memiliki tanah air, dengan demikian mencintai, membelam dan menjaga tanah air meripakan kewajiban umat Islam.

Ekslusifitas yang terjadi dalam realitas kebangsaan harus diminimalisasi sehingga misi Islam Rahmatan Lil'alamin dapat tercapai sebagaimana mestinya. Upaya tersebut dapat dilakukan dengan meyakini bahwa esensi sesungguhnya terdapat dalam kalimat "La Ilaha Illallah" (Tiada Tuhan Selain Allah). Kemudian Nabi Muhamamd SAW meng-

\section{Ibid.}

24 Purwoko, Dwi, dkk. Negara Islam, Percikan Pemikiran: H. Agus Salim, KH. Mas Manshur, Mohammad Natsir, KH. Hasyim Asyari. (Depok: Permata Atika Kreasi, 2001), hlm. 37-38. 
aplikasinnya dengan membangun masyarakat Madinah melalui Piagam Madinah. Piagam Madinah telah memuat nilai-nilai dan pesan Rasullah SAW dan ditegaskan pula melalui Haji Wada agar semua umat untuk saling menghormati, menghargai, memiliki rasa persaudaraan, perdamaian, menghindarkan pertumpahan darah, mengangkat kehormatan wanita, dan seterusnya. ${ }^{25}$

Ciri khas kepribadian bangsa Indonesia yang mengandung normanorma kebaikan merupakan nilai kebangsaan Indonesia yang menjadi pedoman dan tujuan keluruhan bangsa yang abadi dan lestari. Hal tersebut berlaku di masa lampau, masa kini atau untuk masa depan kehidupan bangsa Indonesia. Nilai kepribadian bangsa dapat dibedakan menjadi dua yaitu secara dinamik akan menjadi semangat kebangsaan, sedangkan secara statik terwujud dalam ideologi, dasar negara yang menjadi jati diri bangsa. Semua itu didapatkan dan dikomodasi dari kemajemukan Indonesia. Pancasila, Undang-Undang Dasar (UUD) 1945, Negara Kesatuan Republik Indonesia (NKRI) dan Bhineka Tunggal Ika merupakan nilai kebangsaan Indonesia yang mengacu pada empat pilar kebangsaan. ${ }^{26}$

Nilai kebangsaan yang bersumber dari Pancasila:27 Nilai religius yang terkandung dalam sila pertama memiliki nilai-nilai spiritual berdasarkan keyakinan dan agama yang dipeluk oleh setiap orang yang memiliki toleransi beragama sebagai pengejawantahan dari pengakuan adanya Tuhan Yang Maha Esa. Nilai kekeluargaan yang terkandung dalam sila kedua memiliki nilai senasib sepenanggungan dalam kebersamaan berkebangsaan dan bernegara tanpa membedakan suku, agama, ras, dan antar golongan sebagai kontekstualisasi Indonesia yang merupakan masyarakat majemuk. Nilai persatuan atau keselarasan yang terkandung dalam sila ketiga, nilai keselarasan memiliki kemampuan untuk menerima budaya dan kearifan lokal dan memahami keberagaman dari bangsa yang plural. Nilai kerakyatan yang terkandung dalam sila keempat merupakan wujud kedaulatan rakyat yang mesti adanya keberpihakan terhadap rakyat. Nilai keadilan yang terkandung dalam sila kelima memiliki sifat keberpihakan bagi seluruh rakyat Indonesia.

${ }^{25}$ Siradj, Said Aqiel. Islam Kebangsaan, Fiqih Demokratik Kaum Santri. (Jakarta: Pustaka Ciganjur, 1999), hlm. 193.

26 Lembaga Ketahanan Nasional RI. Naskah Akademik Pedoman Pemantapan Nilai-Nilai Kebangsaan. (Jakarta: Lembaga Ketahanan Nasional RI, 2009), hlm. 39.

27 Idem, hlm. 41. 
Kemudian nilai kebangsaan yang terdapat dalam UUD 1945 diantaranya yaitu pertama: nilai dalam Pembukaan UUD 1945 terdiri atas nilai kemanusiaan, religius, produktivitas, dan keseimbangan. Kedua: nilai dalam pasal-pasal dan ayat-ayat UUD 1945 adalah nilai demokrasi, kesamaan derajat, ketaatan hukum dan ketiga: nilai kebangsaan dalam bentuk NKRI. ${ }^{28}$

Selanjutnya nilai kebangsaan dalam semboyan Bhineka Tunggal Ika meliputi, nilai gotong-royong, kerjasama, nilai keadilan, dan nilai toleransi. Apabila dicermati bahwa Pancasila terefleksi ke dalam nilainilai yang terkandung dalam UUD 1945, NKRI, dan Semboyan Bhineka Tunggal Ika. Hal tersebut terjadi karena Pancasila merupakan ideologi, dasar negara, dan jati diri bangsa Indonesia yang menjadi falsafah sumber nilai kebangsaan Indonesia. ${ }^{29}$

Menurut Paulus Wahana bahwa Pancasila telah memuat nilai kemanusiaan yang berlaku bagi seluruh manusia untuk kapanpun dalam keadaan apapun. Selain itu memiliki nilai dasar aktual dalam setiap tindakan manusia. Pancasila memiliki nilai-nilai yang saling melengkapi satu dengan lainnya dan tidak bertentangan dengan nilai-nilai yang ada dalam bangsa Indonesia. ${ }^{30}$

Secara teoritis, tampaknya tidak ada kesulitan untuk menginternalisasi proses pembangunan nilai-nilai keislaman dalam kebangsaan. Pernyataan ini bukan didasarkan pada kondisi demografi dimana mayoritas bangsa Indonesia beragama Islam, tetapi lebih didasarkan pada fakta ideologis, bahwa Pancasila sebagai falsafah hidup bangsa yang telah lama dipahami, dihayati, bahkan telah diamalkan oleh segenap bangsa Indonesia, tidak ada satu sila pun dari Pancasila itu yang bertentangan dengan nilai-nilai keislaman. Diformalkan atau tidak, nilai-nilai keislaman telah menjiwai Pancasila sejak dahulu, karena Pancasila telah menjadi falsafah pandangan hidup bagi bagi bangsa Indonesia, sebelum Indonesia merdeka bahkan sebelum Pancasila disahkan oleh para founding fathers. Wujud konkret dari implementasi nilai-nilai Pancasila pada setiap individu warga bangsa ini, tidak lain adalah implementasi dari nilai-nilai keislaman. Selain itu, bagi bangsa Indonesia yang religius, sosialisasi dan internalisasi nilai-nilai keagamaan akan lebih mudah diterima untuk

\footnotetext{
28 Idem, hlm. 42.

${ }^{29}$ Idem, hlm. 43.

30 Wahana, Paulus. Filsafat Pancasila. (Yogyakarta: Kanisius, 1993), hlm. 73-74.
} 
dijadikan pedoman hidup. Hal tersebut disebabkan adanya faktor keimanan yang kuat terhadap nilai-nilai kegamaan yang diyakini dan dapat menjamin kehidupan yang selamat, aman dan nyaman baik di dunia maupun kelak di akhirat. ${ }^{31}$

Berdasarkan uraikan di atas, maka proses implementasi nilai-nilai keislaman dalam kebangsaan pada dasarnya adalah usaha sadar dan terencana dalam proses sosialisasi, internalisasi, serta implementasi nilainilai keislaman yang dikemas dalam Pancasila, serta diformulasikan sebagai falsafah hidup bangsa dapat diterima bangsa Indonesia secara utuh karena nilai tersebut telah mencerminkan kehdiupan manusia yang menjunjung tinggi nilai-nilai universal dalam Islam.

Sosialisasi dan internalisasi nilai-nilai keislaman dalam kebangsaan dapat ditempuh melalui 3 (tiga) jalur pendidikan, yaitu: ${ }^{32}$ Jalur pendidikan informal yang berlangsung dalam lingkungan keluarga, dimana keluarga memiliki tanggung jawab utama dalam sosialisasi dan internalisasi nilai-nilai spiritual sebagai upaya pembangunan nilai-nilai keislaman dalam kebangsaan. Strategi yang dapat ditempuh untuk sosialisasi dan internalisasi nilai keagamaan, antara lain melalui keteladanan orang tua, serta intensifikasi kajian agama yang dilakukan di rumah, sekitarnya bahkan di luar rumah. Jalur pendidikan nonformal, penanggung jawabnya adalah pemuka agama atau tokoh masyarakat yang peduli terhadap pembentukan nilai-nilai keislaman dalam kebangsaan. Pada jalur ini internalisasi nilai-nilai keislaman dalam kebangsaan dilakukan melalui khutbah-khutbah pada acara ritual keagamaan, serta kajian kajian intensif tentang keagamaan yang dilakukan oleh masyarakat melalui kelompok kelompok sosial tertentu. Jalur pendidikan formal adalah wujud proses penyelenggaraan pendidikan dalam lembaga lembaga pendidikan yang terstruktur, sistematis, serta profesional yang diselenggarakan oleh pemerintah dan atau masyarakat. Strategi sosialisasi serta internalisasi nilai-nilai keislaman dalam kebangsaan pada jalur ini dilakukan melalui proses pembelajaran agama sesuai dengan standar isi maupun standar proses pembelajaran yang ditentukan oleh Badan Standarisasi Nasional Pendidikan. Selain itu cara lain untuk internalisasi nilai-nilai keislaman dalam kebangsaan pada jalur pendidikan formal dapat dilakukan melalui

31 Surachman, E. 2011. Revitalisasi Nilai-Nilai Keislaman dalam Pembangunan Karakter Bangsa. Jurnal Studi Alquran, Vo. 7, No. 1: 34.

32 Idem, hlm. 35. 
pesan-pesan moral yang dintegrasikan dengan materi pembelajaran yang diterima oleh peserta didik dari guru pada saat proses kegiatan belajar mengajar belajar berlangsung atau bahkan di luar kegiatan belajar mengajar belajar.

\section{Konsep Keislaman dan Keindonesiaan}

Konsep keislaman dan keindonesiaan secara garis besar terdapat dalam 3 (tiga) paradigma. Paradigma integralistik yaitu pemahaman terhadap satu kesatuan yang tidak dapat dipisahkan antara agama dengan negara. Artinya bahwa negara adalah perwujudan lembaga politik juga sebagai lembaga agama. Hal tersebut memiliki konsepsi bahwa kehidupan kenegaraan diatur menggunakan prinsip dan hukum keagamaan (din wa dawlah), sehingga dikenal sebagai agama-negara. ${ }^{33}$ Contohnya yaitu sistem khilafah yang dilaksanakan oleh Rasullah SAW dan khaulafaurasyidin. Adapun tokoh yang mengusung paradigma ini antara lain, Abu Al-A'la Mawdudi, Muhammad Rasyid Ridha, Hasan Al-Turabi, Sayyid Quthb, dan Hasan Al-Bana. ${ }^{34}$

Paradigma sekuleristik yang dikembangkan oleh tokoh Muslim Indonesia Abdurrahman Wahid dan Nurcholis Madjid, serta tokok Muslim non-Indonesia Khalifah Abdul Halim, Muhammad Sa`id Al-Ashmawi, Ameer Ali, Ziya Gokalp, Ghulam Ahmad Parvez, Thaha Husein, Ali AbdulRaziq, Khuda Bakhsh, dan Sayyid Ahmad Khan. ${ }^{35}$ Kata sekuler berasal dari kata saeculum Bahasa Latin yang berkonotasi masa (time) atau waktu yang menunjukkan now atau present (sekarang), dan tempat (location) dinisbatkan kepada dunia (world). ${ }^{36}$ Pemahaman terhadap paradigma ini yaitu adanya pemisahan secara diametral antara negara dengan agama. Pelaksanaan hukumnya yaitu hukum positif terpisah dengan norma dan nilai agama, yang diartikan bahwa norma dan nilai agama berasal dari firman Tuhan, sedangkan hukum positif merupakan buatan manusia.

33 Muhammad, Husein. Islam dan Negara Kebangsaan: Tinjauan Politik. Dalam Ahmad Suaedy. Pergulatan Pesantren dan Demokrasi. (Yogyakarta: LKiS, 2000), hlm. 89.

34 Abdillah, Masykuri. Demokrasi di Persimpangan Makna: Respon Intelektual Muslim Indonesia Terhadap Demokrasi (1966- 1993). (Yogyakarta: Tiara Wacana, 1999), hlm. 57.

35 Tim Kajian Ilmiah Abituren. Simbiosis Negara dan Agama: Reaktualisasi Syari'at dalam Tatanan Kenegaraan. (Kediri: Lirboyo, 2007), hlm. 28-35.

36 Naquib Al-Attas, Syed Muhammad. Islam and Secularism. (Kuala Lumpur: ISTAC, 1993), hlm. 16. Dalam Cecep Supriadi. 2015. Relasi Islam dan Negara: Wacana Keislaman dan Keindonesiaan. Jurnal KALIMAH, Vol. 13, No. 1: 211. 
Wujud konkretnya terdapat kekebasan memeluk agama oleh setiap warganya tanpa ada intervensi dari negara. Ada argumentasi yang menyatakan bahwa di dalam Alquran tidak ada yang secara tegas mengenai kewajiban bentuk dan sistem pemerintahan. ${ }^{37}$ Nabi Muhammad SAW pun ditugaskan hanya menyampaikan risalah agama kepada umatnya, tidak termasuk mengenai adanya perintah kewajiban dalam membentuk bentuk dan sistem pemerintahan. ${ }^{38}$

Paradigma simbiotik telah dikembangkan oleh Muhammad Natsir, Ibnu Khaldun, Hasbi Ash- Shiddieqy, dan Ibnu Taimiyah. Pemahaman dalam paradigma ini bahwa adanya pendapat yang menolak Islam memiliki sistem ketatanegaraan dan menolak Islam hanya mengatur habluminallah (hubungan manusia dengan Sang Pencipta, Allah SWT), tetapi dalam Islam terdapat seperangkat norma dan tata nilai serta etika bagi keberlangsungan kehidupan berbangsa dan bernegara. ${ }^{39}$ Konsep ini menegaskan bahwa adanya hubungan timbal balik antara negara dengan agama, karena negera perlu agama untuk pembinaan spiritual, etika, dan moral, sedangkan agama membutuhkan negara sebagai instrumen menjamin keberlangsungan keberagamaan.40 Menurut Husein Muhammad bahwa paradigma simbiotik memiliki arti Islam berada diposisi yang bersifat teologis, terkadang berada pada posisi pragmatik. ${ }^{41}$ Kewajiban agama dalam mengatur kehidupan manusia dalam kekuasaan negara merupakan upaya tegaknya agama, Ibnu Tamiyah pun menyampaikan bahwa negara dan agama merupakan dua entitas yang berbeda dan saling membutuhkan. Menurutnya bahwa konstitusi atau hukum yang berlaku bukan hanya sekadar dari social contract (kesepakatan bersama) masyarakat, akan tetapai diwarnai juga oleh hukum agama (syari'ah). ${ }^{42}$

Hubungan dengan Indonesia terhadap 3 (tiga) paradigma di atas bahwa Indonesia berada dalam paradigma simbiotik. Fakta dalam implementasinya, negara Indonesia bukan merupakan negara Islam, yang

37 Al-Raziq, Ali Abd. Al-Islam wa Usul Al-Hukmi, (Dar Al-Hilal, Cet. I, 1925), hlm. 64-65. Dalam Cecep Supriadi. 2015. Relasi Islam dan Negara: Wacana Keislaman dan Keindonesiaan. Jurnal KALIMAH, Vol. 13, No. 1: 211.

38 Arief, Abd Salam. 2003. Relasi Agama dan Negara Dalam Perspektif Islam. Jurnal Hermeneia, Vol. 2, No. 2: 281.

${ }^{39}$ Sjadzali, Munawir. Islam dan Tata Negara. (Jakarta: UI Press, 1990), hlm. 1-2.

40 Syamsuddin, Din. 1993. Usaha Pencarian Konsep Negara dalam Sejarah Pemikiran Politik Islam. Jurnal Ulumul Quran, Vol. 4, No. 2: 6.

${ }^{41}$ Muhammad, Husein. Op.Cit., hlm. 94.

42 Al-Mubarak, Muhammad. Ara 'Ibnu Taimiyah Fi Al-Dawlah Wa Madza Tadakhuliha Fi Majal Al-Iqtisadi. (Bairut: Dar Al-Fikr, Tanpa Tahun), hlm. 29. 
segala kehidupan berbangsa dan bernegara atas dasar Islam, tetapi dalam keberlangsungannya terdapat nilai-nilai keislaman, sebagaimana pengamalannya tertuang dalam Pancasila.

Menurut Munawir Sjadzali yang dikutip oleh Toharudin bahwa:43 Islam menurut Munawir Sjadzali adalah sistem kehidupan berbangsa dan bernegara yang memiliki nilai etika, moral, spiritual, inspirasi dan motivasi dalam mengembangkan peradaban di dunia nyata, khususnya di Indonesia. Adapun strategi dalam mewujudkan peradaban di Indonesia melulalui aktualisasi nilai keislaman, keindonesiaan dan kebangsaan, yang menjunjung tinggi nilai-nilai yang tercantum dalam Pancasila. Pancasila secara subtansi mengandung nilai-nilai keislaman yang senantiasa digunakan oleh umat Islam Indonesia untuk membangun bangsa Indonesia yang lebih aman, nyaman, damai, toleransi dan sejahtera.

Hakikat Islam menurut Nurcholis Madjid adalah adanya kesesuaian dengan semangat kemanusiaan yang universal. Pelaksanaan terhadap hal tersebut harus disesuaikan dengan pengetahuan dan pemahaman sosiokultural masyarakat yang terikat dengan ruang dan waktu. ${ }^{44}$ Menurutnya Islam merupakan aspek kehidupan spiritual yang sifatnya pribadi, sedangkan negara sebagai aspek kehidupan duniawi yang sifatnya kolektif dan rasional. Selain itu bahwa adanya pemisahan antara negara dan Islam dipandang perlu sebagai pembeda dalam cara pendekatan dan dimensinya. ${ }^{45}$

Nurcholish menjelaskan juga Islam yang hakiki bukan hanya mengatur kumpulan hukum, struktur atau susunan yang formal dalam pemerintahan dan negara, tetapi adanya aktualisasi tauhid yang memiliki kekuatan spiritual dan mampu mencapai jiwa yang demokratis, inklusif, toleransi dan hanif. Berdasarkan uraian tersebut diharapkan dalam negara tidak berlku sistem teokrasi dan juga tidak berlaku seperti negara sekuler. ${ }^{46}$

43 Toharudin. 2018. Nilai-Nilai Keislaman dan Keindonesiaan dalam Membentuk Karakteristik Peradaban Melayu di Indonesia (Studi Pemikiran Munawir Sjadzali). Jurnal Intelektualita: Keislaman, Sosial, dan Sains, Vol. 7, No. 1: 56.

${ }^{44}$ Sofyan, Ahmad A. Gagasan Cak Nur Tentang Negara dan Islam. (Yogyakarta: Titian Ilahi Press, Cet. I, 2003), hlm. 84-88.

45 Rahman, Budhy Munawwar. Reorientasi Pembaruan Islam. (Jakarta: Democracy Project, 2011), hlm. 357.

46 Idem, hlm. 358-367. 


\section{Ekstremisme/Ghuluw Tantangan Islam Rahmatan Lil'alamin}

Adanya kasus bom Bali I yang terjadi pada tanggal 12 Oktober 2002, kemudian kauss bom Bali II yang terjadi pada tanggal 1 Oktober 2005 dan aksi-aksi pemboman lainnya yang menilai Islam jauh dari harapan Islam Rahmatan Lil'alamin. ${ }^{47}$ Selanjutnya kasus pascabom bunuh diri di Polrestabes Medan, Sumatera Utara yang terjadi pada Selasa 19 November 2019 yang terlah ditangkap oleh Densus 88 Antiteror Polri yaitu 71 orang terduga teroris didalamnya, ${ }^{48}$ mengakibatkan penilaian terhadap umat Islam menjadi bagian yang melakukan kekerasan, ekstremisme, radikalisme, dan terorisme bagi umat manusia lainnya. Padahal sebenarnya Islam adalah agama yang penuh kedamaian, persaudaraan, dan toleransi yang melahirkan keselamatan bagi seluruh alam. Hadirnya pemahaman dari yang bukan sebenarnya terhadap Islam, akhirnya membentuk pemahaman radikal/ekstrem (Arab: ghuluw) terhadap Islam itu sendiri. Berdasarkan telaah sejarah bahwa hal tersebut telah terjadi sejak zaman Rasullah SAW masih hidup yang dilanjutkan oleh orang yang tidak taat kepada Allah SWT dan Rasullah SAW, yang disebut dengan kaum Khawarij pada zaman Khalifah Usman dan Khalifah Ali. Sebuah riwayat menyatakan bahwa:

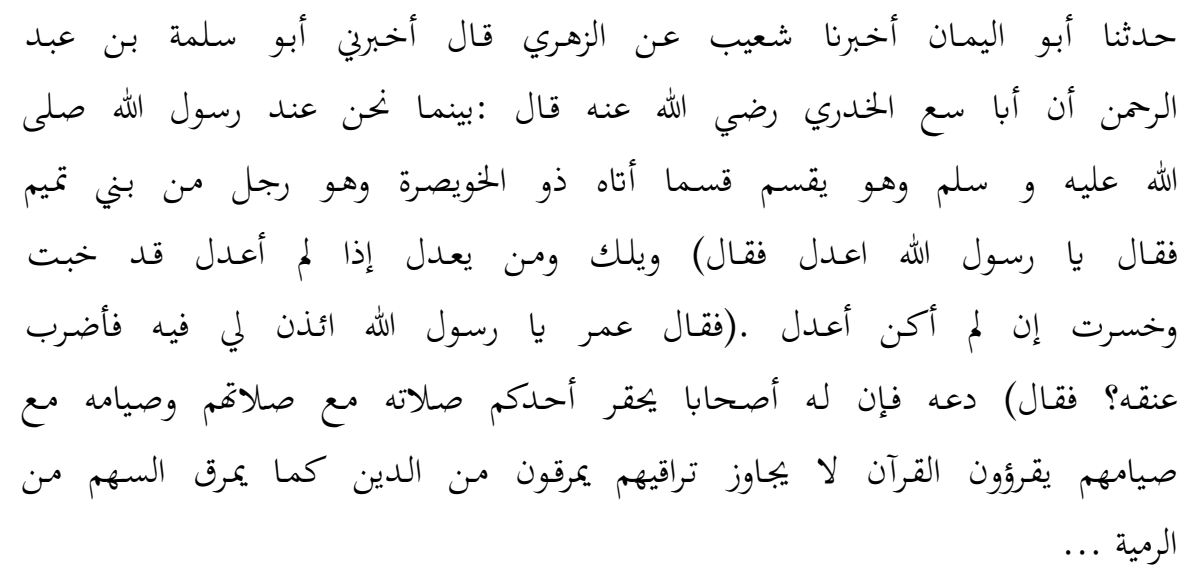

"Suatu hari ketika kami bersama Rasulullah dan beliau sedang melakukan pembagian harta, berkatalah Zul-Khuwaishirah, orang laki-laki dari Bani Tamin, "wahai Rasulullah, berlaku adillah!" Rasulullah menjawab, "Celakalah engkau, siapa yang akan berlaku adil jika aku dianggap tidak berlaku adil?” Umar berkata: “Izinkan-

47 Yahya, Ismail. Op.Cit.

48 Liputan6.com, Jakarta. Op.Cit. 
lah saya memenggal lehernya!" Nabi menjawab: "Jangan, sesungguhnya dia memiliki teman teman yang salah seorang diantara kalian akan minder dengan salat dan puasanya jika dibandingkan dengan salat dan puasa mereka. Mereka membaca Alquran namun tidak melewati Krangkongan mereka, mereka keluar dari agama seperti terlepasnya anak panah dari busurnya." (HR. Bukhari).

Menghindari sikap ekstrem ini sudah diingatkan oleh nabi Muhammad SAW.

$$
\begin{aligned}
& \text { حدثنا علي بن يُمَّمَ حدثنا أبو أسامة عن عوف عن زياد بن الحصين عن أبي العالية عن ابن عبا }
\end{aligned}
$$

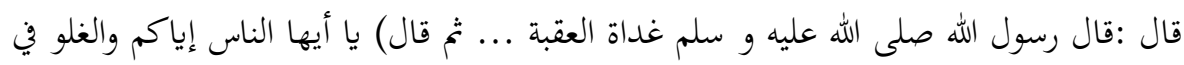

$$
\begin{aligned}
& \text { الدين فإنه أهلك من كان قبلكم الغلو في الدين. }
\end{aligned}
$$

Nabi bersabda: "Wahai manusia berhati-hatilah kalian dari sikap ekstrem dalam beragama, (karena) sesungguhnya sikap seperti itu yang telah menghancurkan umat sebelum kamu. (Lihat HR. Ibnu Majah No.3029).

Menurut Abdurrahman bin Mu'alla al-Luwaihiq (1992: 70-77) dalam Al-Ghuluw Fi Ad-Din Fi Hayah Al-Muslimin Al-Mu'ashirah bahwa radikal/ekstrem atau ghuluw dibagi menjadi 2 (dua) macam, yaitu: alghuluw al-kulli al-i'tiqadi (terkait masalah aqidah) dan al-ghuluw fi al-juz'i al-'amali (terkait masalah perilaku). Adapun beberapa ciri-ciri yang dapat tergolong radikal/ekstrem atau ghuluw dalam memahami agama menurut Yusuf Al-Qardhawi dalam Ash-Shahwah Al-Islamiyyah Bayna Aljuhud Wa At-Tatharruf (terjemahan Indonesia: Membedah Islam "Ekstrem" 2001: 29-49), yaitu: (1) tidak mengakui pendapat orang lain, sehingga menimbulkan fanatik yang berlebihan; (2) adanya kewajiban yang bersumber dari manusia bukan berdasarkan ketetapan Allah SWT; (3) memberlakukan ketetapan yang tidak sesuai sumber aslinya; (3) adanya kekerasan dan kasar, kecuali sanksi hukum dan perang; (4) selalu suudzan (buruk sangka) terhadap manusia; dan (5) sudah untuk mengakifarkan orang lain (takfiri). 49

Adanya fenomena radikal/ekstrem atau ghuluw dalam memahami agama yang terjadi di dunia Islam, khususnya Indonesia disebabkan oleh beberapa faktor. Menurut Yusuf Al-Qardhawi dalam Ash-Shahwah AlIslamiyyah Bayna Al-Juhud Wa At-Tatharruf (terjemahan Indonesia: 
Membedah Islam "Ekstrem" 2001: 50-95) bahwa faktor-faktor tersebut diantaranya adalah sebagai berikut: (1) minimnya ilmu pengetahuan sehingga mengakibatkan lemahnya dalam memahami hakikat agama; (2) hanya memahami secara zahiriyah/harfiyah dalam memahami nash-nash; (3) mempermasalahkan seremonial dan melupakan permasalahan yang pokok; (4) mengharamkan sesuatu secara berlebihan; (5) keliru dalam memahami istilah sehingga salah dalam mengimplemtasikan; (6) cenderung melaksanakan yang mutasyabihat (samar) sehingga meninggalkan yang muhkamat (jelas); (7) mempelajari ilmu pengetahuan bukan dari ahlinya; (8) berpaling dari para ustadz, ulama, habib, dan lainnya; dan (9) minimnya pengetahuan sejarah Islam, sehingga tidak mampu memberikan beberapa alternatif.50

Adapun target strategis yang mudah didiktrinasi oleh kamu esktermis salah satunya adalah sekolah/kampus. Rasullah SAW pun sudah memberikan sinyal terhadap hal tersebut. Dijelaskan dalam ash-Shahiihain, dari 'Ali Radhiyallahu anhu, ia berkata, "Aku mendengar Rasulullah Shallallahu 'alaihi wa sallam bersabda:

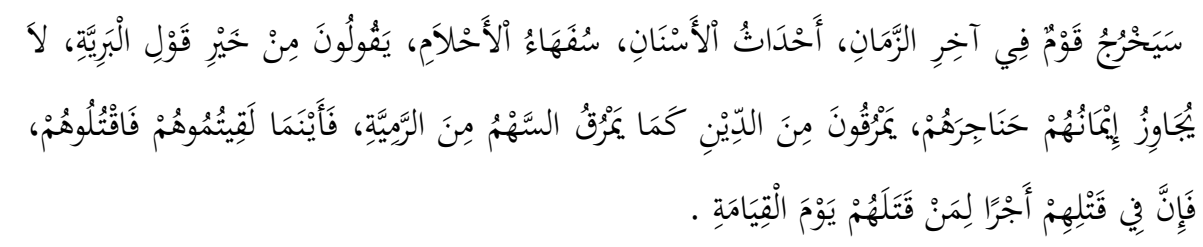

"Akan keluar satu kaum di akhir zaman, (mereka) adalah orangorang yang masih muda, akal mereka bodoh, mereka berkata dengan sebaik-baiknya perkataan manusia, keimanan mereka tidak melewati kerongkongan, mereka keluar dari agama bagaikan anak panah yang keluar dari busurnya, di mana saja kalian menjumpai mereka, maka (perangilah) bunuhlah, karena sesungguhnya dalam memerangi mereka terdapat pahala di hari Kiamat bagi siapa saja yang membunuh mereka."' (Shahiih al-Bukhari (XII/283, al-Fath), dan Shahiih Muslim kitab az-Zakaah, bab at-Tahriidh 'ala Qatlil Khawaarij (VII/169, Syarh an-Nawawi).

Tujuan tersebut diwujudkan oleh kamu muda Khawarij sebagaimana disampaikan oleh Muhammad Tahir-ul-Qadri yang menafsir kata ahdas al-asnan dan sufaha al-ahlam berdasarkan hadits di atas. ${ }^{51}$ Ada beberapa cara untuk menghindari hal tersebut, salah satunya yaitu

51 Tahir-ul-Qadri, Muhammad. Op.Cit, hlm. 337. 
adanya peranan aktif dari keluarga dan sekolah dalam memberikan hakikat pemahaman terhadap Islam Rahmatan Lil'alamin. Peran guru/ dosen dalam hal ini yang memberikan pemahaman terhadap ilmu pengetahuan, teknologi serta sains baik memalui media tertulis ataupun audio visual. Begitu penting belajar dengan guru/dosen atau orang ahli di bidangnya karena belajar tanpa guru menurut Kuntowijoyo diibaratkan sebagai "Muslim tanpa masjid", atau dikenal dengan ungkapan lain juga yang disampaikan kitab-kitab klasik dalam dunia pendidikan Islam seperti Ta'lim al-Muta'allim karya Az-Zarnuji (w. 591/1195) dan Tazkirah as-Sami' wa al-Mutakallim karya Ibnu Jamaah (639-723/1241- 1325) yaitu "Man La Syaikha Lahu Fa Asy-Syaithan Syaikhun Lah."52

Selain adanya peran guru/dosen atau orang ahli di bidangnya, hendaknya setiap orang dapat menghargai perbedaan pendapat, menjungung tinggi nilai toleransi yang diharapkan mewujudkan kedamaian, persaudaraan dan keselamatan bagi seluruh alam.

\section{Penutup}

Konsep dan upaya orang Islam khususnya di Indonesia menjadikan Rahmatan Lil'alamin sebagai perwujudan cita-cita Islam dalam kebangsaan, bukan hanya keselamatan bagi manusia tetapi juga untuk seluruh alam. Rahmatan Lil'alamin sebagai perwujudan cita-cita Islam dalam kebangsaan dapat diaktualisasikan dengan 3 (tiga) cara, yang pertama adalah memiliki ilmu pengetahuan yang luas dan memahami perkembangan teknologi dan sains. Orang yang memiliki ilmu pengetahuan dan teknologi serta sains diharapkan dapat memahami konsep Islam Rahmatan Lil'alamin adalah gagasan yang komprehensif dan holistik sehingga mampu mewjudukan keselamatan manusia tidak ada artinya jika alam tidak dalam keselamatan. Islam yang menyelamatkan adalah Islam yang memberikan keselamatan bagi seluruh alam. Wujud konkret hal ini yaitu melalui pendidikan yang ditempuh seseorang, baik formal, non-formal dan informal adalah kesatuan yang terpadu, untuk membentuk pribadi Muslim yang mampu mengkontekstualisasikan ilmu pengetahuan dan teknologi serta sains yang didapatkannya ke sebuah lingkungan masyarakat. Kedua, Tidak emosi dalam bergama. Orang yang telah memahami konsep Islam Rahmatan Lil'alamin ilmu pengetahuan dan teknologi serta sainsnya akan meningkatkan kedewasaan dalam 
beragama dan melahirkan perdamaian serta kerukunan lintas kelompok, agama, etnis suku dan ras adalah dambaan Islam. Cita-cita itu tidaklah utopis, kedatangan Islam pun untuk mewarnai kehidupan di bumi bagi seluruh alam. Ketiga, Hati-hati dalam setiap ucapan, perbuatan dan tindakan. Orang yang telah memahami konsep Islam Rahmatan Lil'alamin ilmu pengetahuan dan teknologi serta sainsnya, kemudian tidak emosi dalam beragama akan selalu hati-hati dalam setiap ucapan, perbuatan dan tindakan sehingga mampu menjadikan Islam sebagai rahmat bagi seluruh alam, bukan hanya keselamatan bagi manusia tetapi juga untuk alam lainnya, yang diselamatkan adalah hablum minallah, hablum minan nas dan juga hablum minal alam.

\section{Daftar Pustaka}

Abdillah, Abi Muhammad bin Abdirrahman bin Al-Fadhl al-Darami. Kitâb Al-Musnad al-Jâmi. Beirut: Dâr Al-Basyâ'ir Al-Islâmiyah, 2014.

Abdillah, Masykuri. Demokrasi di Persimpangan Makna: Respon Intelektual Muslim Indonesia Terhadap Demokrasi (1966- 1993). Yogyakarta: Tiara Wacana. 1999.

Ahmad, Abi Husain Ibn Faris Ibn Zakariya, Mu'jam Maqâyîsu Al-Lughati, di-tahqiq Abd Salam Muhammad Harun. Vol. 2. Beirut: Dâr Al-Fikr, 1979.

Al-Husain, Abi Al-Qasim Ibn Muhammad (Al-Asfahani), Al-Mufradâtu Fî Gharîbi Al-Qur'âni. Vol. 2. Mekkah: Maktabah Nizâr Mustafa Al-Bâz, 2009

Al-Mubarak, Muhammad. Ara 'Ibnu Taimiyah Fi Al-Dawlah Wa Madza Tadakhuliha Fi Majal Al-Iqtisadi. Bairut: Dar Al-Fikr, t.th.

Al-Raziq, Ali Abd. Al-Islam wa Usul Al-Hukmi, Dar Al-Hilal, Cet. I, 1925.

Arief, Abd Salam. "Relasi Agama dan Negara Dalam Perspektif Islam". Jurnal Hermeneia, Vol. 2, No. 2. (2003).

Armstrong, Karen. Compassion: 12 Langkah Menuju Hidup Berbelas Kasih, Terjemahan Yuliani Liputo. Bandung: Mizan, 2012.

Ath-Thabari. Jami'ul Bayan fi Ta'wil Alquran. Beirut: Mua'assasah ArRisalah, 2000.

Bugin. Metodologi Penelitian Kualitatif. Jakarta: Rajawali Pers, 2011. 
Cabil. "Perwujudan Cita-cita Islam dalam Kebersamaan Kebangsaan". (http://coretanceritacrayon.blogspot.com/2017/10/perwujudancita-cita-islam-dalam.html), diakses pada tanggal 25 Desember 2019.

Cecep Supriadi. "Relasi Islam dan Negara: Wacana Keislaman dan Keindonesiaan”. Jurnal KALIMAH, Vol. 13, No. 1. (2015).

Husaini, Adian dan Nuim Hidayat. Islam Liberal: Sejarah, Konsepsi, Penyimpangan dan Jawabannya. Jakarta: Gema Insani Press, 2002.

Lembaga Ketahanan Nasional RI. Naskah Akademik Pedoman Pemantapan Nilai-Nilai Kebangsaan. Jakarta: Lembaga Ketahanan Nasional RI, 2009.

Liputan6.com, Jakarta. "71 Terduga Teroris Ditangkap Usai Bom Bunuh Diri Medan". (https://www.liputan6.com/news/read/4114911/71-terdugateroris-ditangkap-usai-bom-bunuh-diri-medan), diakses pada tanggal 25 Desember 2019.

Mandzur, Ibnu. Lisânul Arab. Vol. 5. Beirut: Dâr Ihyâ Al-Turâts Al-Arabi, 1999

Muhammad, Husein. Islam dan Negara Kebangsaan: Tinjauan Politik. Dalam Ahmad Suaedy. Pergulatan Pesantren dan Demokrasi. Yogyakarta: LKiS, 2000.

Munawwir, Imam. Salah Paham Terhadap Alquran. Surabaya: PT Bina Ilmu, 1983.

Muzadi, Abdul Muchith. Mengenal Nahdlatul Ulama. Surabaya: Khalista, 2006.

Naquib Al-Attas, Syed Muhammad. Islam and Secularism. Kuala Lumpur: ISTAC, 1993.

Nazir, Moh. Metode Penelitian. Jakarta: Ghalia Indonesia, 2014.

Purwoko, Dwi, dkk. Negara Islam, Percikan Pemikiran: H. Agus Salim, KH. Mas Manshur, Mohammad Natsir, KH. Hasyim Asyari. Depok: Permata Atika Kreasi, 2001.

Rahman, Budhy Munawwar. Reorientasi Pembaruan Islam. Jakarta: Democracy Project, 2011. 
Rasyid, Muhammad Makmun. "Islam Rahmatan Lil Alamin Perspektif KH. Hasyim Muzadi”. Episteme Jurnal Pengembangan Ilmu Keislaman, Vol. 11, No.1. (2016).

Shihab, M. Quraish. Wawasan Al-Quran: Tafsir Maudhu'i Atas Pelbagai Persoalan Umat. Jakarta: Mizan, 1998.

Siradj, Said Aqiel. Islam Kebangsaan, Fiqih Demokratik Kaum Santri. Jakarta: Pustaka Ciganjur, 1999.

Sjadzali, Munawir. Islam dan Tata Negara. Jakarta: UI Press, 1990.

Sofyan, Ahmad A. Gagasan Cak Nur Tentang Negara dan Islam. Yogyakarta: Titian Ilahi Press, Cet. I, 2003.

Sugiyono. Metode Penelitian Kuantitatif, Kualitatif, dan Kombinasi (Mixed Methods). Bandung: Alfabeta, 2014.

Surachman, E. "Revitalisasi Nilai-Nilai Keislaman dalam Pembangunan Karakter Bangsa". Jurnal Studi Alquran, Vo. 7, No. 1. (2011).

Syam, Nur, Merumuskan Islam Rahmatan Lil'alamin, (http://nursyam.uinsby.ac.id/?p=514), dalam Ismail Yahya.

Syamsuddin, Din. "Usaha Pencarian Konsep Negara dalam Sejarah Pemikiran Politik Islam". Jurnal Ulumul Quran, Vol. 4, No. 2. (1993).

Tahir-ul-Qadri, Muhammad. Fatwa tentang Terorisme dan Bom Bunuh Diri. Jakarta: LPPI, 2014.

Tim Kajian Ilmiah Abituren. Simbiosis Negara dan Agama: Reaktualisasi Syari'at dalam Tatanan Kenegaraan. Kediri: Lirboyo, 2007.

Toharudin. "Nilai-Nilai Keislaman dan Keindonesiaan dalam Membentuk Karakteristik Peradaban Melayu di Indonesia (Studi Pemikiran Munawir Sjadzali)". Jurnal Intelektualita: Keislaman, Sosial, dan Sains, Vol. 7, No. 1. (2018).

Wahana, Paulus. Filsafat Pancasila. Yogyakarta: Kanisius, 1993.

Yahya, Ismail. "Islam Rahmatan Lil'alamin". (http://www.iainsurakarta.ac.id/?p=12750), diakses pada tanggal 25 Desember 2019. 
294 | Adliya: Jurnal Hukum dan Kemanusiaan, Vol. 14, No. 2, Desember 2020

[Halaman ini sengaja dikosongkan] 